\title{
Memaknai Peran Pondok Pesantren An-Nuqayah Guluk- Guluk dalam Pengentasan Kemiskinan di Pedesaan
}

\author{
Anis Isti’anah \& Sutikno \\ Program Studi Ekonomi Pembangunan, \\ Universitas Trunojoyo Madura \\ E-mail: istianah.anis@gmail.com
}

\begin{abstract}
Penelitian ini bertujuan untuk: 1) mengetahui konsep pemberdayaan pondok pesantren Annuqayah dalam pengentasan kemiskinan; 2) memaknai peran modal sosial yang dimiliki dalam pelaksanaan kegiatan pemberdayaan pada pondok pesantren Annuqayah. Penelitian ini menggunakan metode pedekatan kualitatif, dengan teknik analisis antara lain: Analisis Life History, Studi Kasus, dan penggunaan bahan dokumentasi. Penelitian ini menemukan bahwa: Pertama, konsep pemberdayaan yang dilakukan oleh pondok pesantren Annuqayah terdapat dua model. Model pertama pemberdayaan menggunakan dakwah bil-hal. Dakwah bil-hal dalam pemberdayaan disini dilakukan dengan membentuk kelompok binaan yang mempunyai masalah sosial dan ekonomi untuk diberikan modal usaha. Model yang kedua pemberdayaan dilakukan dengan cara pemberian tabungan dan pembiayaan tanpa jaminan dan tanpa bunga. Semua kegitan dalam pemberdayaan yang dilakukan oleh Pondok Pesantren Annuqayah berpedoman pada konsep Al-Qur'an dan Hadits. Kedua, modal sosial yang dimiliki oleh pondok pesantren Annuqayah dalam kegiatan pemberdayaan adalah budaya dan tradisi di masyarakat sekitar pesantren yang beriringan dengan agama sehingga menghasilkan sebuah norma agama dan norma kesopanan, kepercayaan yang diberikan antara para pengasuh pondok pesantren dan juga mitra pondok pesantren. Penerapan nilai-nilai seperti kejujuran yang diajarkan oleh pesantren terus melekat pada masyarakat dalam proses pemberdayaan. Konsep kemitraan dengan sistem jaringan yang berupa selalu menjaga tali silaturrahim antara alumni, pesantren dan masyarakat, serta repirositas yang berupa saling membantu antar pesantren dan masyarakat memperlancar terlaksananya pemberdayaan. Semua unsur modal sosial tersebut mempunyai pengaruh yang cukup penting dalam kegiatan pemberdayaan masyarakat di sekitar pesantren Annuqayah.
\end{abstract}

Keywords:Pemberdayaan Ekonomi, Pesantren, Modal Sosial

Vol. 3, No.1, Agustus 2018 


\section{Pendahuluan}

Pesantren merupakan salah satu kelembagaan Islam tertua di Indonesia, bahkan lembaga ini telah menjadi sebuah institusi budaya di Indonesia. Elemen dasar lembaga ini adalah pondok, masjid, pengajaran kitab-kitab klasik, santri dan juga kiai. Dhofier dalam Khozin mengatakan bahwa salah satu kelebihan pesantren terletak pada kemampuannya untuk menciptakan sebuah sikap hidup universal yang merata dan diikuti oleh semua santri sehingga lebih mandiri dan tidak bergantung pada siapapun atau lembaga apapun. ${ }^{1}$ Fase awal berdirinya pesantren mengacu pada pengembangan bidang ilmu pendidikan keagamaan saja. Hal ini ini terlihat dari tiga peran utama pesantren waktu itu yaitu sebagai pusat berlangsungnya transmisi ilmu-ilmu Islam tradisional, sebagai penjaga dan pemeliharaan kelangsungan Islam tradisional dan sebagai pusat pembentukan kader-kader ulama. ${ }^{2}$

Data Kementerian Agama tahun 2012 menyebutkan bahwa jumlah pondok pesantren di Indonesia adalah 27.230 pesantren. Selain itu, jumlah santri di Indonesia secara keseluruhan adalah 3.759 .198 orang. Banyaknya jumlah pesantren merupakan sebuah potensi yang dimiliki Indonesia dalam menggerakkan perekonomian melalui keunikan dan kemandirian yang dimiliki oleh pesantren. Keunikan yang dimiliki pesantren dapat menghasilkan nilai ekonomis yang tinggi jika dikelola dengan profesional. $^{3}$ Seiring dengan perkembangannya, beberapa pondok pesantren yang ada di Indonesia seperti, Pondok Pesantren Gontor, Pondok Pesantren Sidogiri Pasuruan, Pondok Pesantren Langitan Tuban, Pondok Pesantren Lirboyo Kediri, dan Pondok Pesantren Tebuireng Jombang. Pada saat ini pesantren-pesantren tersebut telah mengalami pergesaran fungsi utama pesantren yaitu menjadi sebagai pusat pengkaderan pemikir-pemikir agama Islam (Center of Excellence), sebagai lembaga yang mencetak sumber daya manusia (Human Resource), serta sebagai lembaga yang mempunyai kekuatan melakukan pemberdayaan pada masyarakat (Agent of Development). ${ }^{4}$

Berangkat dari fenomena bergesernya fungsi utama pesantren tersebut maka menarik untuk mengetahui bagaimana peran pondok pesantren Annuqayah GulukGuluk dalam pengentasan kemiskinan di pedesaan dengan tujuan ingin mengetahui konsep pemberdayaan pondok pesantren Annuqayah dalam pengentasan kemiskinan; serta memaknai peran modal sosial yang dimiliki dalam pelaksanaan kegiatan pemberdayaan oleh pondok pesantren Annuqayah. Karena

\footnotetext{
1 A. Khozin, "Peran Pondok Pesantren Modern Bina Insani Terhadap Keberagaman dan Kesejahteraan Masyarakat Dusun Baran Desa Ketapang Kecamatan Susukan Kabupaten Semarang”, (Skripsi Jurusan Tarbiyah STAIN SALATIGA, 2014).

${ }^{2}$ Basori dalam M. M Azmi, "Peran Pondok Pesantren Darul Ulum Dalam Pemberdayaan Ekonomi Masyarakat Dusun Pesantren Paterongan Jombang”, Skripsi Fakultas Ilmu Sosial dan Humaniora UIN Sunan Kalijaga Yogyakarta, 2013).

3 Halim (2005) dalam S. N. Azizah, "Pengelolaan Unit Usaha Pesantren Berbasis Ekoproteksi”, EKBISI, Vol. IX No. 1, (2014), 103-115.

${ }^{4}$ A. Halim, dkk., Manajemen Pesantren, (Yogyakarta: Pustaka Pesantren, 2005).
} 
pada dasarnya setiap pondok pesantren di Indonesia mempunyai cara tersendiri dalam menjalankan fungsinya sebagai lembaga yang mempunyai kekuatan melakukan pemberdayaan pada masyarakat (Agent of Development).

\section{Kerangka Konseptual Penelitian}

Penelitian ini berkaitan dengan teori modal sosial dengan konsep pemberdayaan melalui pondok pesantren. Banyak penelitian yang telah dilakukan tentang modal sosial baik dari segi politik, ekonomi maupun sosial. Penelitian yang dilakukan dalam skala internasional maupun nasional. Beberapa referensi dalam penelitian ini adalah penelitian yang dilakukan oleh Sudarno Shobron dan Imron Rosyadi, serta Mohammad Zaki Suaidy yang berjudul "Dakwah Bil-Hal Pesantren Wali Songo Ngabar Ponorogo Jawa Timur dalam Pemberdayaan Ekonomi Masyarakat tahun 2013-2014”. Penelitian tersebut mendeskripsikan implementasi dan peran dakwah bil-hal PPWS dalam pemberdayaan masyarakat Ngabar dalam rangka mewujudkan masyarakat sejahtera dan mandiri secara ekonomi. Selain itu terdapat pula penelitian yang dilakukan oleh Faishal yang berjudul "Bentuk-Bentuk Pengembangan Ekonomi Masyarakat di Pesantren". Dalam penelitian tersebut diketahui bahwa pondok pesantren Annuqayah memiliki kontribusi positif terhadap pengembangan ekonomi masyarakat dan untuk internal pesantren sendiri. ${ }^{5}$ Dasar teori yang dipakai untuk memaknai peran pesantren dalam pemberdayaan masyarakat adalah Teori Ekonomi Kelembagaan dan Teori Modal Sosial. Untuk mempertajam pembahasan mengenai objek penelitian dan penyamaan persepsi berkaitan dengan objek, maka dalam tinjauan pustaka juga akan dijelaskan konsep pemberdayaan masyarakat dan beberapa hasil penelitian sebelumnya.

Ostrom (1985) dalam Suhana mendefinisikan kelembagaan sebagai aturan dan rambu-rambu sebagai panduan yang dipakai oleh para anggota suatu kelompok masyarakat untuk mengatur hubungan yang saling mengikat atau saling tergantung satu sama lain. ${ }^{6}$ Sedangkan Ahmad Erani Yustika (2006) membagi aliran kelembagaan ke dalam ilmu ekonomi kelembagaan lama (old institutional economics) dan ilmu ekonomi kelembagaan baru (new institutional economics). Aspek ekonomi kelembagaan adalah menyangkut property right atau hak pemilikan dan juga teori modal sosial. ${ }^{7}$ Salah satu ahli yang menjelaskan modal sosial adalah Coleman (1988) dalam Sasongko dan Wahyuni mendefinisikan modal sosial sebagai jaringan informasi, kewajiban dan harapan, norma-norma dan sanksi-sanksi yang efektif sehingga dapat memaksa atau menyemangati

5 A. Faishal, "Bentuk-bentuk Pengembangan Ekonomi Masyarakat di Pesantren (Studi Kasus Atas Pengembangan Ekonomi Masyarakat di PP. Annuqayyah Guluk-guluk Sumenep Madura”. Universitas Islam Negeri Syarif Hidayatullah Jakarta, (2012).

6 Suhana, "Analisis Ekonomi Kelembagaan dalam Pengelolaan Sumberdaya Ikan Teluk Palabuhan Ratu Kabupaten Sukabumi”, Thesis ITB, (2008).

${ }^{7}$ A. E.Yustika, Ekonomi Kelembagaan: Definisi, Teori, dan Strategi, (Malang: Bayu Media, 2006). 
seseorang untuk bertigkah laku dan tetap eksis dalam menjaga hubungan dengan orang lain. ${ }^{8}$ Sedangkan Bourdien (1992) dalam Sasongko dan Wahyuni mendefinisikan modal sosial sebagai sebuah kemampuan yang berkembang pada diri seseorang ataupun kelompok individu untuk membangun sebuah jaringan yang dapat bertahan lama dalam berinteraksi dengan sebuah hal yang dilembagakan berdasarkan pengetahuan dan pengenalan timbal balik. Dari definisi tersebut terdapat lima unsur yang mempengaruhi modal sosial yaitu kepercayaan, jaringan, norma, resiprositas dan juga nilai. ${ }^{9}$

Di sisi lain, terdapat banyak definisi pemberdayaan ekonomi ummat di banyak literatur yang dikemukakan oleh para ahli. Para ahli menggunakan kata "masyarakat" untuk menunjuk makna "ummat". Dari segi kebahasaan, pemberdayaan merupakan terjemahan dari 'empowerment', sedang memberdayakan adalah terjemahan dari 'empower'. Sumodiningrat (1999) menyatakan bahwa pemberdayaan ekonomi adalah usaha untuk menjadikan perekonomian yang kuat, besar, modern, dan berdaya saing tinggi dalam mekanisme pasar yang benar. Pemberdayaan ekonomi ummat adalah semua kegiatan yang bertujuan untuk meningkatkan kemampuan perekonomian ummat baik secara langsung (misalnya: pemberian modal usaha, pendidikan ketrampilan ekonomi, pemberian dana konsumsi), maupun secara tidak langsung (misalnya: pendidikan ketrampilan ekonomi, perlindungan dan dukungan terhadap kaum dengan kondisi ekonomi lemah, dan lain-lain). ${ }^{10}$

\section{Model Pemberdayaan Pondok Pesantren Annuqayah Guluk-Guluk}

Pelaksanaan fungsi dan peran Pondok Pesantren Annuqayah sebagai lembaga yang mempunyai kekuatan melakukan pemberdayaan pada masyarakat (agent of change) dilakukan sejak tahun 1978 melalui Biro Pengabdian Masyarakat (BPMPPA) dan juga melalui Unit Jasa Keuangan Syariah (UJKS) Annuqayah pada tahun 2014. BPM-PPA merupakan sebuah organisasi nirlaba dan non-pemerintah (NGO) yang mengkhususkan pada upaya-upaya penguatan masyarakat (civil society), dengan cara pendampingan, pembinaan dan pengembangan melalui organisasi berbasis masyarakat. Pembinaan yang dilakukan Pondok Pesantren Annuqayah dilakukan dengan cara membentuk kelompok-kelompok masyarakat binaan yang terdiri dari petani, pengrajin dan juga pedagang kecil dengan memberikan pendidikan pola-pola pertanian inovatif, keterampilan dan bentukbentuk kerajinan baru serta kredit bahan pertanian dan intensif modal tanpa bunga (Pengelola Pondok, 2017)

${ }^{8}$ Sasongko, Y. A., \& Wahyuni, E. S., "Diaspora Madura: Analisis Modal Sosial Dalam Usaha Sektor Informal Oleh Migran Madura Di Kecamatan Tanah Sareal, Kota Bogor, Jawa Barat”, Jurnal Sosiologi Pedesaan, Vol. 01, No. 01, (2013), 52-63.

${ }^{9}$ Ibid., Sasongko, Y. A., \& Wahyuni, E. S., ...., 52-63.

10 Gunawan Sumodiningrat, Pemberdayaan Masyarakat dan Jaring Pengaman Sosial, (Jakarta: Gramedia Pustaka Utama, 1999). 
Cara membentuk kelompok binaan dilakukan dengan dua cara yaitu pertama, dari permintaan masyarakat yang biasanya diminta dari alumni Pondok Pesantren Annuqayah yang merasa daerah sekitarnya perlu pengembangan ekonomi. Kedua, dengan cara mencari daerah, khususnya sekitar pondok pesantren yang dirasa perlu intervensi dari pondok pesantren seperti daerah yang masyarakatnya terjebak dalam cengkraman rentenir. Tahapan intervensi dilakukan dengan cara melakukan pendekatan terhadap kelompok pemuda ataupun kepada tokoh masyarakat. Melalui mereka pendekatan dilakukan agar dapat mengajak masyarakat yang terjebak dalam cengkraman rentenir dapat berkumpul dan sosialisai pemberdayaan dapat dilakukan. Untuk menyampaikan visi-misi pembinaannya, BPM-PPA menggunakan media komunikasi tradisional masyarakat seperti pengajian. BPM-PPA juga menjadikan masyarakat sebagai mitra dalam kegiatannya (Informan, 2017). Berbagai kegiatan pelatihan dan pengembangan keterampilan bagi masyarakat telah diselenggarakan oleh BPMPPA. Berikut beberapa program dari BPM-PPA yang berkaitan dengan peningkatan ekonomi kerakyatan beserta dakwah bil-hal yang pernah dilakukannya.

\section{Tabel 1.1: Program BPM-PPA Yang Pernah Dilakukan Beserta} Dakwah Bil-Hal

\begin{tabular}{|c|c|c|}
\hline Program & Dakwah bil-hal & Tujuan \\
\hline $\begin{array}{lr}\text { 1) } & \begin{array}{l}\text { Ternak } \\
\text { dengan } \\
\text { gaduh }\end{array} \\
\text { sistem }\end{array}$ & 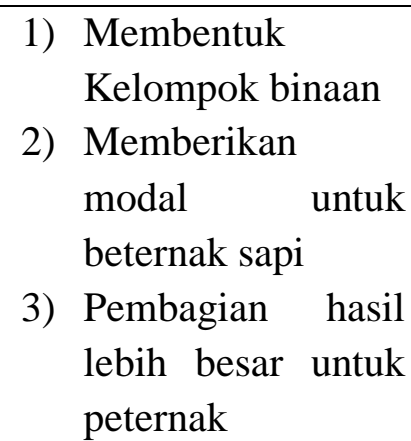 & $\begin{array}{l}\text { Membantu } \\
\text { masyarakat khususnya } \\
\text { kelompok binaan agar } \\
\text { mempunyai peternakan } \\
\text { pribadi }\end{array}$ \\
\hline $\begin{array}{l}\text { 2) Budidaya Jamu } \\
\text { Herbal }\end{array}$ & 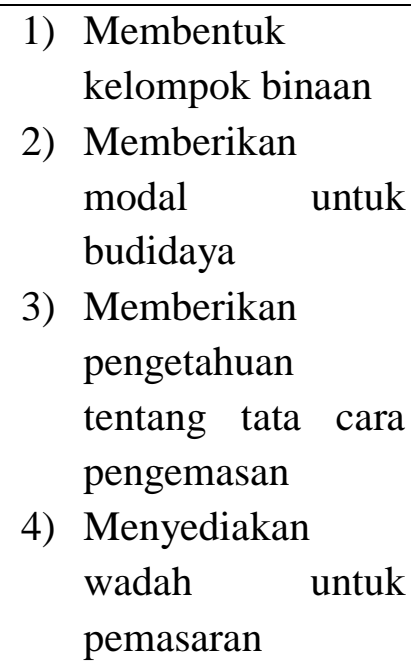 & $\begin{array}{l}\text { 1) Untuk menjaga } \\
\text { keberlangsungan } \\
\text { obat herbal } \\
\text { tradisional } \\
\text { 2) Untuk menguatkan } \\
\text { ekonomi } \\
\text { kelompok- } \\
\text { kelompok } \\
\text { masyarakat. Atau } \\
\text { mendorong } \\
\text { terbentuknya } \\
\text { kelompok }\end{array}$ \\
\hline
\end{tabular}




\begin{tabular}{|c|c|c|}
\hline & & $\begin{array}{l}\text { masyarakat } \\
\text { 3) Mendorong } \\
\text { beberapa orang } \\
\text { dari kelompok } \\
\text { untuk membuka } \\
\text { pengobatan } \\
\text { tradisioanal } \\
\text { menggunakan } \\
\text { herbal dan } \\
\text { pengetahuan } \\
\text { tradisional tentang } \\
\text { "sangkal gulung” }\end{array}$ \\
\hline $\begin{array}{l}\text { 3) Peningkatan } \\
\text { usaha lembaga } \\
\text { jejaring } \\
\text { Annuqayah } \\
\text { (ikatan alumni) }\end{array}$ & 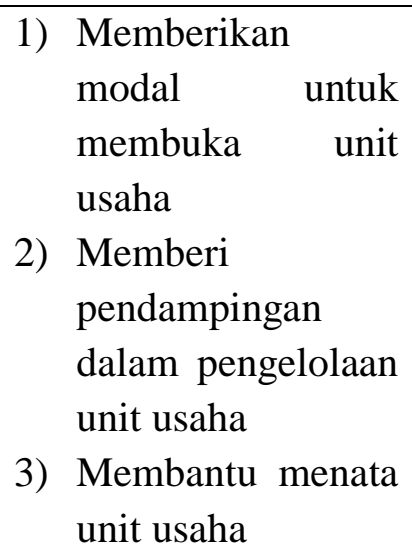 & \begin{tabular}{l}
\multicolumn{1}{c}{ Untuk membantu } \\
menguatkan lembaga \\
jejaring annuqayah \\
(ikatan alumni) di \\
berbagai daerah
\end{tabular} \\
\hline
\end{tabular}

Sumber: Hasil Wawancara dengan Informan, diolah, (2017)

Selain program-program yang disebutkan di atas, BPM-PPA juga mempunyai program-program sebelumnya seperti pada tahun 1978 BPM-PPA melakukan adopsi rekayasa teknologi tepat guna, seperti industri kecil, ferro semen, bamboo semen, teknologi pertanian, dan unit pengolahan limbah. Pada tahun 1980-an, BPM-PPA melaksanakan pendidikan alternatif yang bekerjasama dengan LP3ES, P3M Jakarta, GTZ Jerman, USC Canada, Bandung Forum, PKBI, Yayasan Bina Anaprasa Surabaya, Yayasan KEHATI Jakarta, FADO RI, dan sebagainya. Pada tahun 1995 BPM-PPA melaksanakan program penggemukan sapi melalui laserpungtur yang dilaksanakan bekerjasama dengan Fakultas Peternakan Universitas Brawijaya Malang dan Universitas Airlangga Surabaya (Pengelola Pondok, 2017)).

Ada beberapa tujuan dalam kegiatan pemberdayaan/ pengabdian masyarakat yang dilakukan oleh BPM-PPA yaitu terciptanya masyarakat yang dapat mengatur pola dan konsumsi dan pola ekonomi sesuai dengan paradigma pesantren yaitu sebagai hamba Allah. Segala aspek kehidupan seorang hamba Allah seharusnya dilakukan dalam rangka persembahannya kepada Allah SWT dengan niat hanya 
untuk mencapai keridhaan-Nya. Hal ini sesuai dengan firman Allah SWT sebagai berikut:

"Dan tidaklah Aku menciptakan jin dan manusia melainkan untuk beribadah kepada-Ku (saja)” (QS. Adz-Dzariyaat[51]: 56)

Sebagai umat muslim maka harus memahami benar posisinya dihadapan Allah SWT sebagai 'abid atau hamba atau Abdullah. Tugas manusia sebagai Abdullah (Hamba Allah) yaitu harus menjaga hubungan baiknya kepada Allah SWT (hablumminallah) seperti sholat, puasa, haji maupun menjaga hubungan baik terhadap sesama manusia (hablumminannas) seperti menjalankan kegiatan muamalah dengan sesama manusia sesuai dengan ketentuan Allah SWT dan hadist. Seperti yang dijelaskan dalam hadist berikut:

Dari Abu Hurairah ra berkata, bahwasanya Rasululla bersabda: "Barangsiapa menghilangkan kesulitan seorang mukmin di dunia, maka Allah akan melepaskan kesulitannya pada hari kiamat. Barangsiapa memudahkan orang yang tengah dilanda kesulitan, maka Allah akan memudahkannya di dunia dan di akhirat. Barangsiapa menutup aib seorang Muslim, maka Allah akan menutupi aibnya di dunia dan di akhirat. Dan Allah akan menolong hamba-Nya selama hamba itu menolong saudaranya. Dan barangsiapa yang menempuh suatu jalan dalam rangka mencari ilmu, maka Allah akan memudahkan baginya jalan menuju surga. Tidaklah suatu kaum di salah satu rumah Allah, membaca kitab Allah dan mempelajarinya bersama-sama, kecuali ketentraman akan turun kepada mereka, rahmat akan memenuhi mereka, malaikat menaungi mereka, dan Allah memuji mereka di hadapan makhluk yang berada di sisi-Nya. Barangsiapa yang terlambat amalnya, maka nasabnya tidak akan mempercepat (nasibnya)" (HR. Muslim)

Sedangkan tujuan yang lainnya adalah untuk membentuk santri yang siap terjun dalam kegiatan masyarakat. Berdasarakan hasil temuan seperti yang dijelaskan di atas, maka dapat gambarkan model pemberdayaan masyarakat yang dilakukan pondok pesantren Annuqayah melalui Biro Pengabdian Masyarakat seperti berikut: 

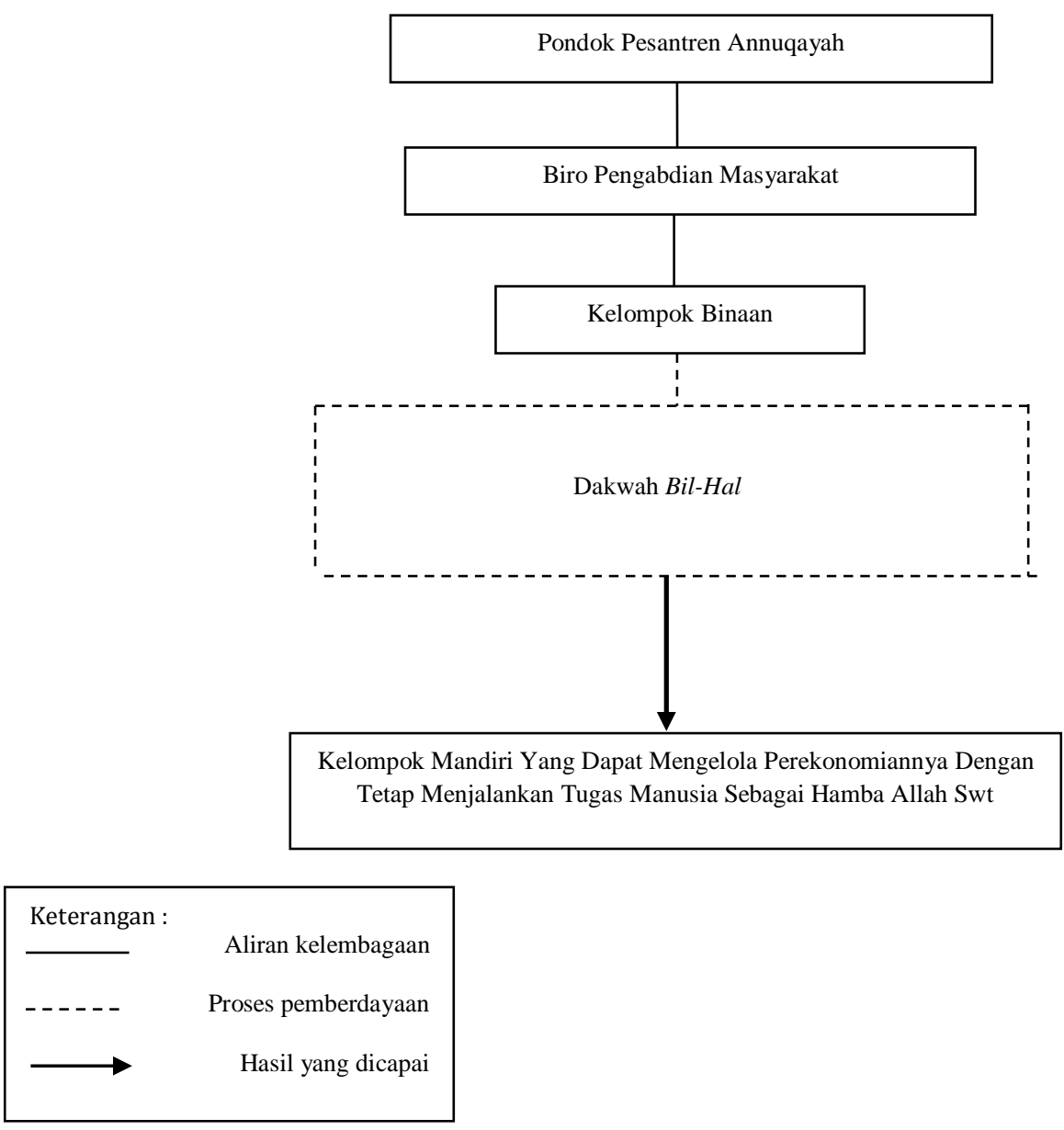

Sumber : hasil wawancara, data diolah

Gambar 1.1: Model Pemberdayaan Masyarakat Melalui Pondok Pesantren Annuqayah

Sedangkan Pada tahun 2014, pondok pesantren Annuqayah merintis Unit Jasa Keuangan Syariah Annuqayah yang berada di bawah Koppontren Annuqayah. Sebelumnya UJKS ini bernama Lembaga Keuangan Annuqayah. Hal tersebut karena para kiai pondok pesantren Annuqayah merasa berat dengan kata "syariah" seperti yang digunakan oleh lembaga keuangan lainnya. UJKS ini memberdayakan para alumni pondok pesantren Annuqayah yang memiliki kemampuan di bidang perbankan dan mempunyai banyak pemahaman tentang muamalah. Para alumni yang mempunyai kemampuan di bidang tersebut direkrut dan juga diberi kompensasi setiap bulannya. Kompensasi tersebut hampir setara dengan UMK Kabupaten Sumenep. Tujuan utama UJKS ini adalah ingin mengcover seluruh pengabdi pondok pesantren. Semboyan UJKS Annuqayah adalah "BERBAGI MANFAAT, MENGUATKAN EKONOMI UMAT". UJKS Annuqayah memiliki 2 produk yaitu tabungan dan pembiayaan. Akad yang 
mereka gunakan dalam produk tabungan adalah wadi'ah yad al-dhamanah yang atas seijin nasabah dapat digunakan untuk pengembangan UJKS Annuqayah. Sedangkan dalam produk deposito islamika menggunakan akad Mudharabah Muqayyadah yaitu simpanan yang diperlakukan sebagai investasi dan dikelola secara produktif professional untuk pengembangan layanan UJKS Annuqayah. Dalam pembiayaan akad yang mereka gunakan adalah murabahah. Akad murabahah adalah perjanjian jual beli antara nasabah dengan bank. (Informan, 2017).

UJKS Annuqayah mempunyai prinsip-prinsip khas untuk membantu masyarakat khususnya pengabdi dan karyawan pesantren. Prinsip-prinsip tersebut adalah membantu masyarakat yang membutuhkan tanpa bunga ataupun istilah bagi hasil menurut ekonomi syariah serta tidak ada jaminan untuk produk pinjaman. Karena istilah bagi hasil yang dikembangkan oleh ekonomi syariah tetap mempersulit masyarakat tidak mampu menurut para pengasuh pondok pesantren Annuqayah (informan, 2017). Produk simpan-pinjam yang ditawarkan oleh UJKS Annuqayah tidak menggunakan jaminan dan tanpa bunga karena berdasarkan pada asas koperasi yaitu kekeluargaan. Selain itu, mereka juga menggunakan prinsip yang diajarkan oleh Rasulullah SAW. Menurut mereka Rasulullah SAW tidak mengajarkan sistem jaminan kecuali dalam gadai sedangkan mereka tidak menyediakan kegiatan gadai. Selain itu, mereka seharusnya masyarakat muslim itu dibangun atas rasa persaudaraan dan saling percaya. Untuk menyelesaikan permasalah Simpan-pinjam, UJKS Annuqayah mempunyai solusi yang mereka anut dari Rasulullah SAW. Tahapan yang mereka lakukan yaitu pertama mengingatkan, jika masyarakat tidak sanggup membayar maka mereka akan menangguhkan atau bahkan dibebaskan. Dalil yang menjelaskan tentang penangguhan hutang adalah sebagai berikut:

"Dan jika (orang yang berhutang itu) dalam kesukaran, maka berilah tangguh sampai dia berkelapangan. Dan menyedekahkan (sebagian atau semua utang) itu, lebih baik bagimu, jika kamu mengetahui.” (QS. Al Baqarah[2]: 280)

Selain itu, Rasulullah shallallahu 'alaihi wa sallam bersabda,

"Barangsiapa memberi tenggang waktu bagi orang yang berada dalam kesulitan untuk melunasi hutang atau bahkan membebaskan utangnya, maka dia akan mendapat naungan Allah." (HR. Muslim)

Semua kegiatan pengelolaan keuangan baik itu produk tabungan maupun pembiayan, dilakukan secara mandiri oleh Unit Jasa Keuangan Syariah Annuqayah. Mereka mengola sendiri semua kegiatannya keuangannya tanpa melibatkan lembaga keuangan lainnya seperti BMT ataupun Bank Konvensional. Hal itu karena perintah dari pengasuh pondok pesantren Annuqayah yang menjaga 
prinsip mereka yang berpatokan pada Al-Qur'an dan Hadist dan menjaga nama baik "syariah". Dari temuan seperti yang dijelaskan di atas maka dapat digambarkan bagaimana model pemberdayaan pondok pesantren Annuqayah melalui Unit Jasa Keuangan Syariah seperti berikut:
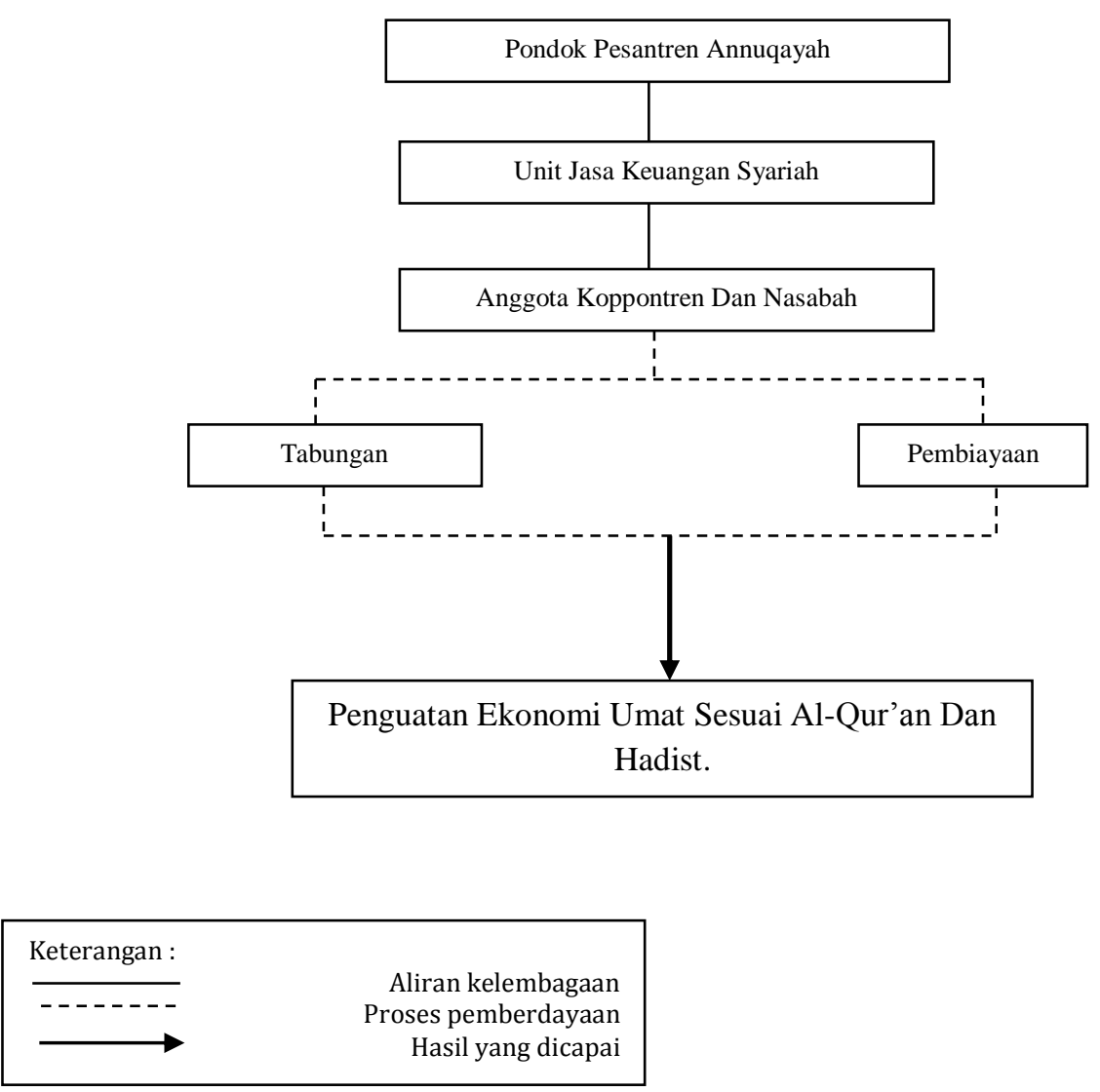

Sumber : hasil wawancara, data diolah

Gambar 2.1: Model Pemberdayaan Melalui Unit Jasa Keuangan Syariah Annuqayah

\section{Modal Sosial Pondok Pesantren Annuqayah}

Ada beberapa jenis modal dalam melaksanakan program pemberdayaan. Salah satunya adalah modal sosial. Ife dan Tesoriero (2008) dalam Rizal menjelaskan mengenai modal sosial dalam pengembangan masyarakat merupakan modal yang dapat digunakan sebagai kekuatan penggerak dalam program pemberdayaan. Modal sosial memberikan dukungan kepada masyarakat untuk melakukan tindakan secara bersama-sama sehingga ada imbal balik yang diperoleh. ${ }^{11}$

11 D. A. Rizal, "Pemberdayaan Masyarakat Berbasis Kelompok Tani: Studi Kemitraan Pemerintahan Daerah Kabupaten Sleman dengan Kelompok Tani Tri Tunggal Wonorejo, Sariharjo, Kecamatan Ngaglik Kabupaten Sleman”, Skripsi Jurusan Pengembangan Masyarakat Islam Fakultas Dakwah Universitas Islam Negeri Sunan Kalijaga, (2014). 
Secara umum modal sosial mencakup tiga unsur utama seperti yang telah dikemukakan oleh Putnam (1993) dalam Sasongko dan Wahyuni yaitu kepercayaan, jaringan, dan norma. ${ }^{12}$

Dari hasil wawancara dengan para informan dapat diketahui bahwa Pondok Pesantren Annuqayah memiliki berbagai modal sosial yang hidup di masyarakatnya. Modal sosial tersebut sesungguhnya sudah lama hidup dan bersemayam dalam kearifan lokal masyarakat di lingkungan pondok pesantren Annuqayah. Modal sosial tersebut mempunyai peran tersendiri dalam mengembangkan kegiatan pengembangan masyarakat yang dilakukan oleh pondok pesantren Annuqayah. Modal sosial yang dimiliki oleh pondok pesantren Annuqayah adalah budaya dan tradisi Desa Guluk-Guluk yang di dalamnya melibatkan agama dalam segala urusan hidupnya tidak terkecuali dalam urusan ekonomi. Tradisi ini tidak terlepas dari peran pondok yang dipelopori oleh pondok pesantren Annuqayah, penerapan nilai Shiddiq atau kejujuran, pemberian kepercayaan penuh terhadap masyarakat sekitar, ikatan alumni yang erat, dan juga sikap tolong-menolong antara pondok pesantren dengan Annuqayah. Kondisi ini dapat dimaknai sebagi modal sosial seperti ynag terdapat pada unsur-unsur modal sosial yang dijelaskan oleh Bourdian (1992), ${ }^{13}$ dimiliki oleh pondok pesantren Annuqayah. Modal sosial yang dominan di pondok pesantren Annuqayah adalah norma agama dan norma kesopanan yang berasal dari budaya dan tradisi masyarakat Desa Guluk-Guluk.

\section{Kesimpulan}

Terdapat dua model dalam Pelaksanaan fungsi dan peran Pondok Pesantren Annuqayah sebagai lembaga yang mempunyai kekuatan melakukan pemberdayaan pada masyarakat (agent of change). Model pertama pemberdayaan menggunakan bentuk dakwah bil-hal. Dakwah bil-hal dilakukan dengan cara membentuk sebuah kelompok binaan. Kelompok binaan tersebut didapat dari permintaan masyarakat seperti alumni yang merasa daerahnya perlu intervensi pondok pesantren, misalnya daerah yang masyarakatnya terjebak dalam cengkraman rentenir. Masyarakat yang mempunyai masalah sosial dan ekonomi tersebut dibentuk kelompok untuk diberi pembinaan. Selanjutnya kelompok yang sudah terbentuk diberi modal oleh pondok pesantren Annuqayah melalui Biro Pengabdian Masyarakat untuk dijadikan modal usaha. Usaha yang dikerjakan dapat berupa peternakan maupun pertanian.

Hasil dari kegiatan pemberdayaan yang dilakukan adalah masyakarat khususnya kelompok binaan dapat mengelola perekonomiannya secara baik dan benar serta mandiri sesuai dengan ajaran agama yang menjelaskan bahwa manusia

12 Sasongko, Y. A., \& Wahyuni, E. S., "Diaspora Madura: Analisis Modal Sosial Dalam Usaha Sektor Informal Oleh Migran Madura Di Kecamatan Tanah Sareal, Kota Bogor, Jawa Barat”, Jurnal Sosiologi Pedesaan, Vol. 01, No. 01, (2013), 52-63.

${ }^{13}$ P. Baourdian, \& L. Wacquant, An Invitation to Reflexive Sociology, University of Chicago, (1992). 
mempunyai tugas sebagai hamba Allah SWT. seperti yang dijelaskan dalam AlQur'an (QS. Adz-Dzariyat[51]: 56. Kegiatan pemberdayaan tersebut bertujuan untuk membantu masyarakat sekitar mereka terapkan karena mengacu pada hadist riwayat Muslim. Sedangkan model yang kedua pemberdayaan ekonomi dilakukan melalui tabungan dan pembiayaan. Kegiatan tersebut dilakukan melalui Unit Jasa Keuangan Syariah Annuqayah. Pembiayaan dan tabungan yang disediakan oleh Unit Jasa Keuangan Syariah Annuqayah tanpa jaminan dan tanpa bunga. Hal tersebut dilakukan karena Unit Jasa Keuangan Syariah Annuqayah juga berpatokan pada Al-qur'an dan Hadist dalam pelaksanaannya. Dalam ajaran agama islam setiap manusia adalah saudara dan wajib untuk saling tolongmenolong, terutama dalam hal kebaikan. Selain itu, mereka juga mempunyai prinsip menolong sesamanya yang terjerat hutang. Menurut mereka sebagai umat muslim maka wajib hukumnya membantu sesama yang terjerat hutang dengan cara menangguhkan atau membebaskan sesuai dengan Al-Qur'an (QS. Al Baqarah[2]: 280) maupun hadist riwayat muslim No. 3006. Sehingga semua kegiatan pengelolaan keuangan dilakukan secara mandiri oleh Unit Jasa Keuangan Syariah Annuqayah tanpa terlibat dengan lembaga keuangan lainnya seperti BMT ataupun Bank Konvensional. Nasabah UJKS Annuqayah terbatas pada karyawan, pengabdi, santri, dan wali santri pondok pesantren Annuqayah saja.

Dalam melakukan kegiatan pemberdayaan tersebut pondok pesantren Annuqayah mempunyai modal sosial. Modal sosial yang dimiliki oleh pondok pesantren Annuqayah adalah: a) budaya dan tradisi desa guluk-guluk yang di dalamnya melibatkan agama yang dipelopori oleh pondok pesantren Annuqayah, b) penerapan nilai Shiddiq atau kejujuran, c) pemberian kepercayaan penuh terhadap masyarakat sekitar, d) ikatan alumni yang erat, dan juga sikap tolongmenolong antara pondok pesantren dengan Annuqayah. Modal sosial tersebut diharapkan dapat menunjang terlaksanya program pemberdayaan, sehingga dapat menarik masyarakat agar dapat berpartisipasi secara langsung atau dapat menjadi mitra pondok pesantren Annuqayah. Kegiatan pemberdayaan yang dilakukan oleh pondok pesantren Annuqayah dapat dikatakan berhasil karena masyarakat yang menjadi mitra pondok pesantren merasakan dampak terhadap perekonomiannya. Keberhasilan tersebut tentunya tidak terlepas dari modal sosial yang dimiliki pesantren sejak awal kegiatan pengembangan masyarakat dilakukan yaitu sekitar tahun 1978.

\section{Daftar Pustaka}

Al-Qur'an dan Tafsirnya, Departemen Agama Republik Indonesia, 2011

Azizah, S. N. (2014). Pengelolaan Unit Usaha Pesantren Berbasis Ekoproteksi. EKBISI, Vol. IX No. 1, 103-115.

Azmi, M. M. (2013). Peran Pondok Pesantren Darul Ulum Dalam Pemberdayaan Ekonomi Masyarakat Dusun Pesantren Paterongan Jombang. Skripsi Fakultas Ilmu Sosial dan Humaniora UIN Sunan Kalijaga Yogyakarta . 
Baourdian, P., \& Wacquant, L. (1992). An Invitation to Reflexive Sociology. University of Chicago .

Basori, R. (2006). The Founding Father Pesantren Modern Indonesia Jejak Langkah KH. A Wachid Hasyim. Jakarta: Inceis.

Coleman, J. (1988). Social Capital in the Creation of Human. The American Journal of Sociology, Vol.94.

Dhofier, Z. (2011). Tradisi Pesantren Studi Tentang Pandangan Hidup Kiyai. Jakarta: LP3ES.

Faishal, A. (2012). Bentuk-bentuk Pengembangan Ekonomi Masyarakat di Pesantren (Studi Kasus Atas Pengembangan Ekonomi Masyarakat di PP.Annuqayyah Guluk-guluk Sumenep Madura. Universitas Islam Negeri Syarif Hidayatullah Jakarta .

Halim, A., \& dkk. (2005). Manajemen Pesantren. Yogyakarta: Pustaka Pesantren.

Khozin, A. (2014). Peran Pondok Pesantren Modern Bina Insani Terhadap Keberagaman dan Kesejahteraan Masyarakat Dusun Baran Desa Ketapang Kecamatan Susukan Kabupaten Semarang. Skripsi Jurusan Tarbiyah STAIN SALATIGA .

Rizal, D. A. (2014). Pemberdayaan Masyarakat Berbasis Kelompok Tani : Studi Kemitraan Pemerintahan Daerah Kabupaten Sleman dengan Kelompok Tani Tri Tunggal Wonorejo, Sariharjo, Kecamatan Ngaglik Kabupaten Sleman. Skripsi Jurusan Pengembangan Masyarakat Islam Fakultas Dakwah Universitas Islam Negeri Sunan Kalijaga .

Sasongko, Y. A., \& Wahyuni, E. S. (2013). DIASPORA MADURA: ANALISIS MODAL SOSIAL DALAM USAHA SEKTOR INFORMAL OLEH MIGRAN MADURA DI KECAMATAN TANAH SAREAL, KOTA BOGOR, JAWA BARAT. Jurnal Sosiologi Pedesaan, Vol. 01, No. 01, p. 52-63.

Shobron, S., \& Rosyadi, I. (2015). DAKWAH BIL-HẦL PESANTREN WALISONGO NGABAR PONOROGO JAWA TIMUR DALAM PEMBERDAYAAN EKONOMI MASYARAKAT TAHUN 2013-2014. PROFETIKA, Jurnal Studi Islam, Vol. 16, No. 1, 26-49.

Suhana. (2008). ANALISIS EKONOMI KELEMBAGAAN DALAM PENGELOLAAN SUMBERDAYA IKAN TELUK PALABUHANRATU KABUPATEN SUKABUMI. Thesis ITB .

Sumodiningrat, Gunawan. (1999). Pemberdayaan Masyarakat dan Jaring Pengaman Sosial. Jakarta: Gramedia Pustaka Utama.

Yustika, A.E. (2006). Ekonomi Kelembagaan: Definisi, Teori, dan Strategi. Malang: Bayu Media. 